\title{
CORRELATIONS BETWEEN SOMATOTYPES AND NUTRITIONAL INTAKE IN SPORTS STUDENTS
}

\author{
Christoph Raschka, Susanne Kerstin Aichele \\ Institute of Sports Sciences, Julius Maximilians University Würzburg, Germany
}

\begin{abstract}
This explorative control study investigates the correlations between nutritional intake (macronutrient) and somatotypes and other body constitutional types in 94 sports students $(40 \hat{\jmath}, 54$, the age span 20-46 years). Anthropometric data and computed constitutional and somatotypical parameters correspond to international standards. Nutrient intakes were estimated by the use
\end{abstract} of 3-day dietary recall records.

Correlations between individual somatotypes or constitutional types after Conrad or Knussmann and the nutritional intake in the physical education students collective were generally weak, with only a few significant relationships identified:

For female physical education students, there are significant inverse relationships between body fat and protein $(\mathrm{r}=-0.4, \mathrm{p} \leq 0.01)$ and carbohydrate intake $(\mathrm{r}=-0.3, \mathrm{p} \leq 0.01)$, between $\mathrm{BMI}$ and protein $(\mathrm{r}=-0.3, \mathrm{p} \leq 0.01)$, fat $(\mathrm{r}=-0.3, \mathrm{p} \leq 0.05)$, carbohydrate $(\mathrm{r}=-0.2, \mathrm{p} \leq 0.05)$ and energy $(\mathrm{r}=-0.3, \mathrm{p} \leq 0.05)$ intake as well between endomorphy and protein $(\mathrm{r}=-0.4, \mathrm{p} \leq 0.01$ Parnell; $\mathrm{r}=-0.3, \mathrm{p} \leq 0.01 \mathrm{Heath} /$ Carter$)$ and carbohydrate intake $(\mathrm{r}=-0.2, \mathrm{p} \leq 0.05$ Parnell; $\mathrm{r}=-0.4, \mathrm{p} \leq 0.01$ Heath/Carter), between mesomorphy and fat $(\mathrm{r}=-0.3$, $\mathrm{p} \leq 0.05$ Heath/Carter), carbohydrate $(\mathrm{r}=-0.3, \mathrm{p} \leq 0.05$ Heath/Carter $)$ and energy intake ( $\mathrm{r}=-0.3, \mathrm{p} \leq 0.01$ Heath/Carter, $\mathrm{r}=-0.3, \mathrm{p} \leq 0.05$ Parnell). Positive relationships exist between the ectomorphy and protein $(\mathrm{r}=0.2, \mathrm{p} \leq 0.05$ Parnell; $\mathrm{r}=0.3, \mathrm{p} \leq 0.05$ Heath/Carter), fat ( $\mathrm{r}=0.3, \mathrm{p} \leq 0.01$ Heath/Carter) and energy $(\mathrm{r}=0.2, \mathrm{p} \leq 0.05)$ intake.

For the male physical education students, there are significant inverse relationships between body fat and protein $(\mathrm{r}=-0.4, \mathrm{p} \leq 0.01)$ as well as fat $(\mathrm{r}=-0.4$, $\mathrm{p} \leq 0.01)$, carbohydrate $(\mathrm{r}=-0.3, \mathrm{p} \leq 0.05)$ and energy intake $(\mathrm{r}=-0.4, \mathrm{p} \leq 0.01)$, between BMI and fat $(\mathrm{r}=-0.4, \mathrm{p} \leq 0.01)$ and energy intake $(\mathrm{r}=-0.3, \mathrm{p} \leq 0.05)$ as well as between endomorphy and protein $(\mathrm{r}=-0.3, \mathrm{p} \leq 0.05$ Parnell and Heath/ 
Carter), fat ( $\mathrm{r}=-0.4, \mathrm{p} \leq 0.01$, Parnell and Heath/Carter) carbohydrate intake $(\mathrm{r}=-0.3, \mathrm{p} \leq 0.05$ Heath/Carter) and energy intake $(\mathrm{r}=-0.3, \mathrm{p} \leq 0.05$ Parnell; $\mathrm{r}=-0.4, \mathrm{p} \leq 0.01 \mathrm{Heath} /$ Carter), mesomorphy (Heath/Carter) and fat $(\mathrm{r}=-0.4$, $\mathrm{p} \leq 0.01)$, carbohydrate $(\mathrm{r}=-0.3, \mathrm{p} \leq 0.05)$ and energy intake $(\mathrm{r}=-0.3, \mathrm{p} \leq 0.01)$, between pyknomorphy and fat intake $(\mathrm{r}=-0.3, \mathrm{p} \leq 0.05)$ and energy intake $(\mathrm{r}=-0.5, \mathrm{p} \leq 0.01)$.

Positive relationships exist between the ectomorphy (Parnell and Heath/ Carter) and fat intake $(r=0.4$ and $r=0.4, p \leq 0.05)$ as well as between MetrikIndex and fat intake $(\mathrm{r}=0.3, \mathrm{p} \leq 0.05)$. The results indicate that differences may exist between the sexes in these correlations. Further follow-up studies are necessary to clarify these issues.

Keywords: somatotypes, nutritional intake, sports anthropology, correlations

\section{INTRODUCTION}

In our first exploratory study [12] correlations between individual somatotypes and nutritional intake in a collective of 121 members of a fitness studio $(47 \hat{\jmath}$, mean age $37.4 \pm 11.8$ years, 74 , mean age $41.2 \pm 12.6$ years) were registered. These relationships were surprising at first glance, but generally weak, with only a few significant relationships identified.

In detail, the Plastik-Index after Conrad [2] was positively related to protein intake $(r=0.28)$ in women, the Metrik-Index was positively related to fat intake $(r=0.22)$ and energy intake $(r=0.25)$. In men the Plastik index after Conrad was positively correlated to water intake $(r=0.38)$. In women Ectomorphy after Parnell was positively correlated to energy intake $(r=0.23)$, Endomorphy after Heath \& Carter was inversely related to carbohydrate intake $(r=-0.19)$ and energy intake $(r=-0.24)$. In women Mesomorphy after Heath \& Carter was inversely related to carbohydrate intake $(r=-0.21)$ and energy intake $(r=-0.22)$. In women Pyknomorphy after Knußmann was positively correlated to protein intake ( $\mathrm{r}=0.23$ ) and Makrosomia after Knußmann was positively correlated to protein intake. In men Makrosomia after Knußmann was positively correlated to protein intake $(r=0.26)$, carbohydrate intake $(r=0.31)$, energy intake $(r=0.34)$ and water intake $(\mathrm{r}=0.40)$.

So the present explorative control study investigates the correlations between nutritional intake (macronutrient) and somatotypes and other body constitutional types in 94 sports students ( $40 \hat{\jmath}, 54 \uparrow$, age span $20-46$ years). 


\section{MATERIAL AND METHODS}

In this study 94 physical education students $(40 \hat{\jmath}$, mean age $26.2 \pm 4.3$ years, height $183.4 \pm 6.4 \mathrm{~cm}$, weight $80.4 \pm 10.8 \mathrm{~kg} ; 54$, the mean age $24.2 .2 \pm 2.8$ years, height $167.4 \pm 5.4 \mathrm{~cm}$, weight $60.9 \pm 6.9 \mathrm{~kg}$ ) were examined. Each proband participated voluntarily and the data were used anonymously.

Anthropometric data and computed constitutional and somatotypical parameters in this work correspond to international standards $[2,4,5,6,8,10$, 14]. Nutrient intakes were estimated by the use of self-reported, 3-day dietary recall records of food and beverage consumption. The records (macronutrient) were quantified by means of the TANITA Health \& Food Manager software program. The analysis of differences was tested by ANOVA, correlations were tested by the Pearson correlation coefficients.

\section{RESULTS}

The distribution of constitutional types after Conrad [2] and the somatotypes after Parnell [9] and Heath \& Carter [4, 5] are summarized in Figures 1-3.

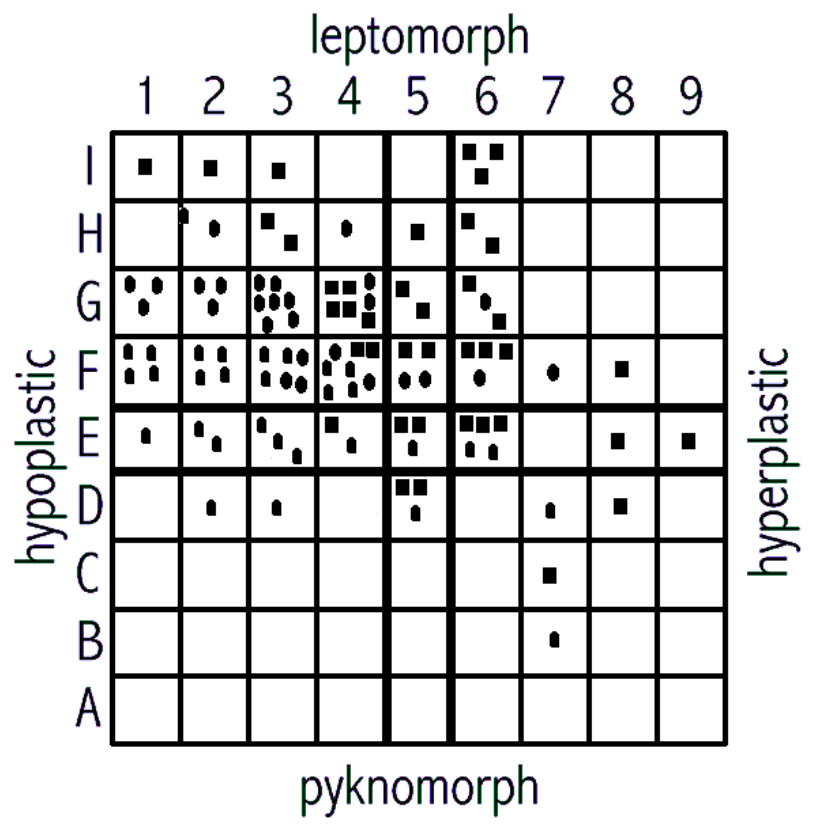

Figure 1. Male (squares; $\mathrm{n}=40$ ) and female (circles; $\mathrm{n}=54$ ) sports students in the chessboard pattern graphic after Conrad [2]. 


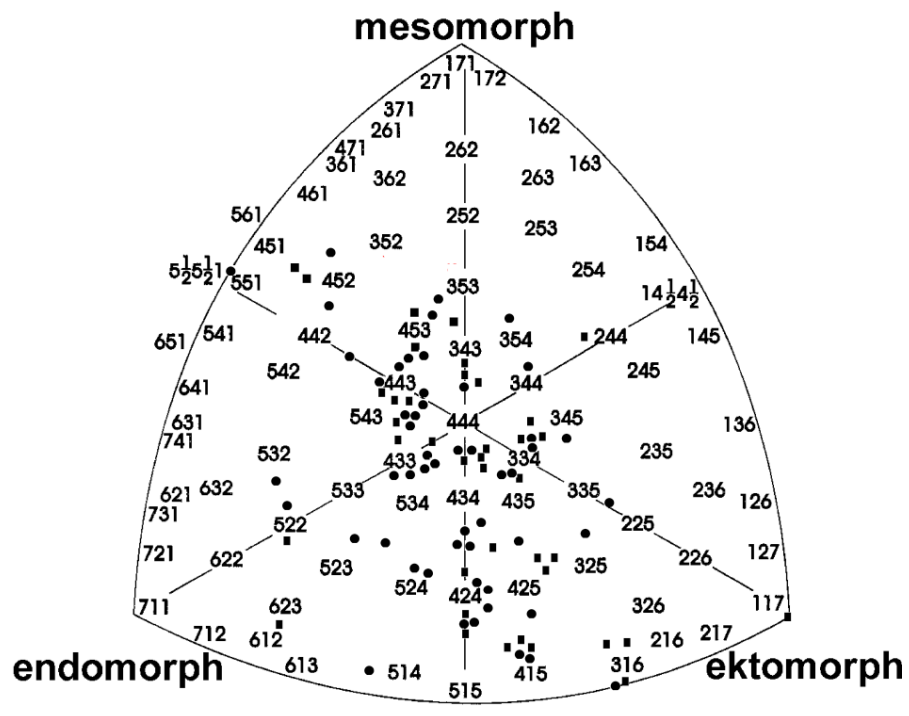

Figure 2. Male

(squares; $n=40$ )

and female

(circles; $\mathrm{n}=54$ )

sports students

in the soma-

tochart after

Parnell [9].

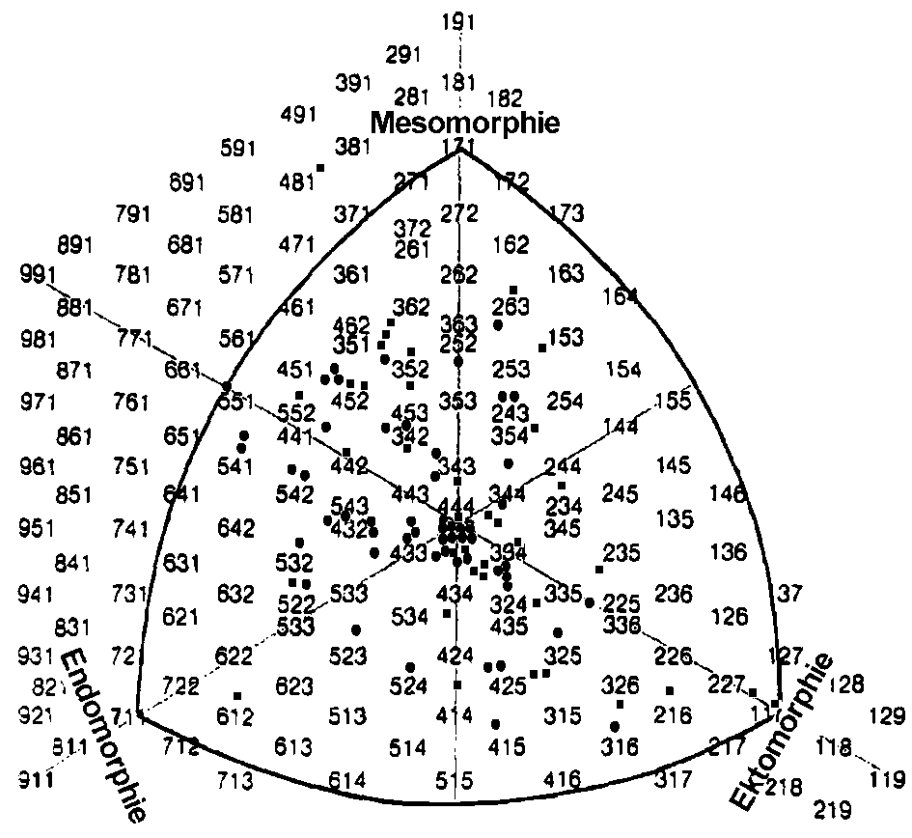

Figure 3. Male (squares;

$\mathrm{n}=40$ ) and female (circles; $\mathrm{n}=54$ ) sports students in the somatochart after Heath and Carter $[4,5]$.

The nutritional intake (macronutrient) of both genders and the correlation coefficients after Pearson between constitutional types / somatotypes and nutritional intake are shown in tables 1-3. 
Table 1. Nutritional intake (macronutrient) of both genders

\begin{tabular}{lccccc}
\hline $\begin{array}{l}\text { Nutritional } \\
\text { Intake }\end{array}$ & $\begin{array}{c}\text { Protein } \\
(\mathbf{g} / \mathbf{d})\end{array}$ & $\begin{array}{c}\text { Fat } \\
(\mathbf{g} / \mathbf{d})\end{array}$ & $\begin{array}{c}\text { Carbohydrates } \\
(\mathbf{g} / \mathbf{d})\end{array}$ & $\begin{array}{c}\text { Energy } \\
(\mathbf{k c a l} / \mathbf{d})\end{array}$ & $\begin{array}{l}\text { Water } \\
(\mathbf{m l} / \mathbf{d})\end{array}$ \\
\hline $\begin{array}{l}\text { Women } \\
(\mathrm{n}=54)\end{array}$ & $72.8 \pm 28.7$ & $70.0 \pm 35.6$ & $272.5 \pm 162.7$ & $2040.4 \pm 670.5$ & $3019.3 \pm 938.2$ \\
\hline $\begin{array}{l}\text { Men } \\
(\mathrm{n}=40)\end{array}$ & $112.5 \pm 42.5^{\star \star *}$ & $109.8 \pm 42.7^{* *}$ & $358.3 \pm 113.9^{* \star *}$ & $2970.8 \pm 920.4^{\star * *}$ & $3120.6 \pm 1055.5$ \\
\hline
\end{tabular}

Table 2. Correlations between constitutional parameters and nutritional intake for the female sports students

\begin{tabular}{|c|c|c|c|c|c|}
\hline $\mathbf{R}$ & $\begin{array}{l}\text { Protein } \\
\text { intake }\end{array}$ & $\begin{array}{c}\text { Fat } \\
\text { intake }\end{array}$ & $\begin{array}{l}\text { Carbo- } \\
\text { hydrate } \\
\text { Intake }\end{array}$ & $\begin{array}{l}\text { Energy } \\
\text { Intake }\end{array}$ & $\begin{array}{l}\text { Water } \\
\text { Intake }\end{array}$ \\
\hline Lean Body Mass & n.s. & n.s. & n.s. & n.s. & n.s. \\
\hline Body Fat Percentage & $-0.4^{\star \star}$ & n.s. & $-0.3^{* *}$ & n.s. & n.s. \\
\hline BMI & $-0.3^{\star \star}$ & $-0.3^{*}$ & $-0.2^{*}$ & $-0.3^{*}$ & n.s. \\
\hline Weight & n.s. & n.s. & n.s. & n.s. & n.s. \\
\hline Fat Mass & $-0.3^{\star \star}$ & n.s. & $-0.3^{\star}$ & n.s. & n.s. \\
\hline Metrik-Index after Conrad & n.s. & n.s. & n.s. & n.s. & n.s. \\
\hline Plastik-Index after Conrad & n.s. & n.s. & n.s. & n.s. & n.s. \\
\hline Pyknomorphy after Knußmann & n.s. & n.s. & n.s. & n.s. & n.s. \\
\hline Makrosomia after Knußmann & n.s. & n.s. & n.s. & n.s. & n.s. \\
\hline Endomorphy after Parnell & $-0.4^{\star \star}$ & n.s. & $-0.2^{*}$ & n.s. & n.s. \\
\hline Mesomorphy after Parnell & n.s. & n.s. & n.s. & $-0.3^{*}$ & n.s. \\
\hline Ectomorphy after Parnell & $0.2^{*}$ & n.s. & n.s. & n.s. & n.s. \\
\hline Endomorphy after Heath\&Carter & $-0.3^{\star \star}$ & n.s. & $-0.4^{\star \star}$ & n.s. & n.s. \\
\hline Mesomorphy after Heath\&Carter & n.s. & $-0.3^{*}$ & $-0.2^{*}$ & $-0.3^{\star \star}$ & n.s. \\
\hline Ectomorphy after Heath\&Carter & $0.3^{*}$ & $0.3^{\star \star}$ & n.s. & $0.2^{*}$ & n.s. \\
\hline
\end{tabular}

For the female physical education students, there are signifiant inverse relationships between body fat and protein and carbohydrate intake, between BMI and protein, fat, carbohydrate and energy intake as well as between endomorphy and protein and carbohydrate intake, between mesomorphy and fat, carbohydrate and energy intake. Positive relationships exist between the ectomorphy and protein, fat and energy intake. 
Table 3. Correlations between constitutional parameters and nutritional intake for the male sports students

\begin{tabular}{|c|c|c|c|c|c|}
\hline $\mathbf{R}$ & $\begin{array}{l}\text { Protein } \\
\text { intake }\end{array}$ & $\begin{array}{c}\text { Fat } \\
\text { intake }\end{array}$ & $\begin{array}{c}\text { Carbo- } \\
\text { hydrate } \\
\text { Intake }\end{array}$ & $\begin{array}{l}\text { Energy } \\
\text { Intake }\end{array}$ & $\begin{array}{l}\text { Water } \\
\text { Intake }\end{array}$ \\
\hline Lean Body Mass & n.s. & n.s. & n.s. & n.s. & n.s. \\
\hline Body Fat Percentage & $-0.4^{\star \star}$ & $-0.4^{\star \star}$ & $-0.3^{\star}$ & $-0.4^{\star \star}$ & n.s. \\
\hline BMI & n.s. & $-0.4^{\star \star}$ & n.s. & $-0.3^{*}$ & n.s. \\
\hline Weight & n.s. & n.s. & n.s. & n.s. & n.s. \\
\hline Fat Mass & $-0.3^{*}$ & $-0.4^{\star \star}$ & n.s. & $-0.4^{*}$ & n.s. \\
\hline Metrik-Index after Conrad & n.s. & $0.3^{*}$ & n.s. & n.s. & n.s. \\
\hline Plastik-Index after Conrad & n.s. & n.s. & n.s. & n.s. & n.s. \\
\hline Pyknomorphy after Knußmann & n.s. & $-0.3^{*}$ & n.s. & $-0.5^{\star \star}$ & n.s. \\
\hline Makrosomia after Knußmann & n.s. & n.s. & n.s. & n.s. & $0.3^{*}$ \\
\hline Endomorphy after Parnell & $-0.3^{*}$ & $-0.4^{\star *}$ & n.s. & $-0.3^{*}$ & n.s. \\
\hline Mesomorphy after Parnell & n.s. & n.s. & n.s. & n.s. & n.s. \\
\hline Ectomorphy after Parnell & n.s. & $0.3^{*}$ & n.s. & n.s. & n.s. \\
\hline Endomorphy after Heath\&Carter & $-0.3^{*}$ & $-0.4^{\star \star}$ & $-0.3^{*}$ & $-0.4^{\star \star}$ & n.s. \\
\hline Mesomorphy after Heath\&Carter & n.s. & $-0.4^{\star \star}$ & $-0.3^{*}$ & $-0.3^{\star \star}$ & n.s. \\
\hline Ectomorphy after Heath\&Carter & n.s. & $0.4^{*}$ & n.s. & n.s. & n.s. \\
\hline
\end{tabular}

For the male physical education students, there are significant inverse relationship between body fat and protein, fat, carbohydrate and energy intake, between BMI and fat and energy intake as well as between endomorphy and protein, fat, carbohydrate and energy intake, mesomorphy and fat, carbohydrate and energy intake, between pyknomorphy and fat intake and enery intake.

Positive relationships exist between the ectomorphy and fat intake as well as between the Metrik-Index and fat intake.

\section{DISCUSSION}

It is well established that diet influences the body composition and certain anthropometric parameters. There is also evidence of an association between physique and the nutritional status. Tanner et al. [13] and Gordon et al. [3] demonstrated a relationship between total serum cholesterol and somatotype. Both studies revealed that endomorphs had the highest, whereas ectomorphs had the lowest serum cholesterol concentrations; men, but not women, exhibited this relationship. On the other side, there are only limited data evaluating the relationship between somatotypes and nutritional intake. 
Correlations between individual somatotypes or the constitutional types after Conrad [2] or Knussmann [6] and the nutritional intake in the physical education students collective were generally weak, with only a few significant relationships identified:

For female physical education students, there are significant inverse relationships between body fat and protein $(\mathrm{r}=-0.4, \mathrm{p} \leq 0.01)$ and carbohydrate intake $(\mathrm{r}=-0.3, \mathrm{p} \leq 0.01)$, between $\mathrm{BMI}$ and protein $(\mathrm{r}=-0.3, \mathrm{p} \leq 0.01)$, fat $(\mathrm{r}=-0.3, \mathrm{p} \leq 0.05)$, carbohydrate $(\mathrm{r}=-0.2, \mathrm{p} \leq 0.05)$ and energy $(\mathrm{r}=-0.3, \mathrm{p} \leq 0.05)$ intake as well as between endomorphy and protein $(\mathrm{r}=-0.4, \mathrm{p} \leq 0.01$ Parnell; $\mathrm{r}=-0.3, \mathrm{p} \leq 0.01$ Heath/Carter) and carbohydrate intake ( $\mathrm{r}=-0.2, \mathrm{p} \leq 0.05$ Parnell; $\mathrm{r}=-0.4, \mathrm{p} \leq 0.01 \mathrm{Heath} /$ Carter), between mesomorphy and fat $(\mathrm{r}=-0.3, \mathrm{p} \leq 0.05$ Heath/Carter), carbohydrate ( $\mathrm{r}=-0.2, \mathrm{p} \leq 0.05$ Heath/Carter) and energy intake $(\mathrm{r}=-0.3, \mathrm{p} \leq 0.01$ Heath/Carter, $\mathrm{r}=-0.3, \mathrm{p} \leq 0.05$ Parnell). Positive relationships exist between the ectomorphy and protein $(r=0.2, p \leq 0.05$ Parnell; $r=0.3, p \leq 0.05$ Heath/Carter), fat $(r=0.3, p \leq 0.01$ Heath/Carter) and energy $(r=0.2, p \leq 0.05)$ intake.

For the male physical education students, there are significant inverse relationships between body fat and protein $(\mathrm{r}=-0.4, \mathrm{p} \leq 0.01)$ as well as fat $(\mathrm{r}=-0.4$, $\mathrm{p} \leq 0.01)$, carbohydrate $(\mathrm{r}=-0.3, \mathrm{p} \leq 0.05)$ and energy intake $(\mathrm{r}=-0.4, \mathrm{p} \leq 0.01)$, between BMI and fat $(r=-0.4, p \leq 0.01)$ and energy intake $(r=-0.3, p \leq 0.05)$ as well as between endomorphy and protein $(\mathrm{r}=-0.3, \mathrm{p} \leq 0.05$ Parnell and Heath/ Carter), fat ( $\mathrm{r}=-0.4, \mathrm{p} \leq 0.01$, Parnell and Heath/Carter) carbohydrate intake $(\mathrm{r}=-0.3, \mathrm{p} \leq 0.05$ Heath/Carter) and energy intake $(\mathrm{r}=-0.3, \mathrm{p} \leq 0.05$ Parnell; $\mathrm{r}=-0.4, \mathrm{p} \leq 0.01 \mathrm{Heath} /$ Carter), mesomorphy (Heath/Carter) and fat $(\mathrm{r}=-0.4$, $\mathrm{p} \leq 0.01)$, carbohydrate $(\mathrm{r}=-0.3, \mathrm{p} \leq 0.05)$ and energy intake $(\mathrm{r}=-0.3, \mathrm{p} \leq 0.01)$, between pyknomorphy and fat intake $(r=-0.3, p \leq 0.05)$ and energy intake $(\mathrm{r}=-0.5, \mathrm{p} \leq 0.01)$.

Positive relationships exist between the ectomorphy (Parnell and Heath/ Carter) and fat intake ( $\mathrm{r}=0.3$ and $0.4, \mathrm{p} \leq 0.05)$ as well as between Metrik-Index and fat intake $(\mathrm{r}=0.3, \mathrm{p} \leq 0.05)$.

In the already presented data from the preliminary study in the introduction clear correlations between diet and physique could be found in 121 members of a fitness studio [12]. These findings for somatotypes are in partial agreement with the results of Bolonchuk et al. [1] who examined somatotypes and nutritional status of 63 men ages 18-40 years who had been recruited for participation in studies to determine nutrient requirements in North Dakota. In this study Endomorphy was inversely related to carbohydrate intake $(r=-0.294, p<$ $0.05)$. In contrast Mesomorphy was directly correlated with fat intake $(\mathrm{r}=0.286$, $\mathrm{p}<0.05$; Bolonchuk et al. [1]). 
Raschka et al. [12] investigated the correlations between nutritional intake and the body build in 50 ultra long distance runners (42 sportsmen and 13 sportswomen), who participated in a $1000 \mathrm{~km}$-race, daily running $50 \mathrm{~km}$. In this collective Endomorphy after Heath \& Carter $[4,5]$ was negatively correlated to energy intake $(r=-0.6, p<0.001$, carbohydrate intake $(r=-0.5, p<0.001)$ and fat intake ( $\mathrm{r}=-0.4, \mathrm{p}<0.001)$, and Endomorphy after Parnell [9] was inversely correlated to energy intake $(\mathrm{r}=-0.4, \mathrm{p}<0.001)$, carbohydrate intake $(\mathrm{r}=-0.4)$ and fat intake $(\mathrm{r}=-0.3, \mathrm{p}<0.01)$.

In summary, there is a series of various studies revealing moderate to weak correlations between the different types of constitution and the supply of macronutrients. The results indicate that differences may exist between the genders in these correlations. Further follow-up studies should clarify these issues.

\section{REFERENCES}

1. Bolonchuk W., Siders W. A., Lykken G. I., Lukaski H. C. (2000). Association of dominant somatotype of men with body structure, function during exercise, and nutritional assessment. Am J Human Biology 12, 167-180.

2. Conrad K. (1963). Der Konstitutionstypus. Berlin: Springer Verlag.

3. Gordon E., Tobias P. V., Mendelsohn D., Seftel H., Howson A. (1987). The relationship between somatotype and serum lipids in male and female young adults. Hum Biol 59, 459-465.

4. Heath B. H., Carter L. J. E. (1967). A modified somatotype method. Am J Phys Anthrop 27, 57-74.

5. Heath B. H., Carter L. J. E. (1990). Somatotyping-development and applications. Cambridge Studies in Biological Anthropology. Great Britain: Redwood Press.

6. Knußmann R. (1996). Vergleichende Biologie des Menschen. Lehrbuch der Anthropologie. Stuttgart: Gustav Fischer Verlag.

7. Kretschmer E. (1921). Körperbau und Charakter. Berlin: Springer Verlag.

8. Martin R., Knussmann R. (1988). Anthropologie. Handbuch. Band I. Stuttgart: Fischer Verlag

9. Parnell R. W. (1954). Somatotyping by physical anthropometry. Am J Phys Anthrop 12, 209-239.

10. Raschka C. (2006). Sportanthropologie. Köln: Sportverlag Strauß.

11. Raschka C., Plath M., Bernhard W., Jung K., Leitzmann C. (1993). Über die Beziehungen zwischen Nährstoffzufuhr und Konstitutionstyp, am Beispiel eines Langstreckenläuferkollektivs. Homo 44, 278-283.

12. Raschka C., Graczyk J. (2013). Correlations between somatotypes and nutritional intake in members of a fitness studio. Papers on Anthropology XXII, 145-152. 
13. Tanner J. M., Israelson W. J., Whitehouse R. H. (1960). Physique and body composition as factors affecting success in different athletic events. J Sports Med Phys Fit 14, 397-411.

14. Tittel K. Wutscherk H. (1972). Sportanthropometrie. Leipzig: Barth.

\section{Adress for correspondence}

Priv.-Doz. Dr.med. Dr.rer.nat. Dr.Sportwiss. Christoph Raschka

Institute of Sports Sciences, Julius-Maximilians-University, Germany

Judenbühlweg 11

D-97082 Würzburg

E-mail: christoph.raschka@uni-wuerzburg.de 